\title{
The Existential Search of the European Banking Authority
}

\author{
Eilís Ferran ${ }^{1}$
}

Published online: 27 September 2016

(C) The Author(s) 2016. This article is published with open access at Springerlink.com

\begin{abstract}
The European Banking Authority (EBA), an EU agency that works to ensure effective and consistent prudential regulation and supervision across the European banking sector as a whole, was established several years before the European Central Bank (ECB) became responsible for the prudential supervision of euro area banks. The ECB's assumption of supervisory responsibilities has prompted searching questions about whether the EBA can continue to add value. The EBA could function as the bridge between the ECB and the supervisory authorities of the Member States that do not participate in European Banking Union and, as such, could help to preserve the integrity of the Single Market. This article locates the EBA's prospects for success in this role more in its ability to manage coexistence than to direct the conduct of supervision. The inquiry is placed within lines of governance scholarship that have moved away from simple 'command and control' models to more complex frameworks. The inquiry is supported by detailed examination of the EBA's performance in key areas, including rule-making, interpretation, and stress testing. Close study reveals that the EBA cannot be expected significantly to prove its value on the supervisory side through its use of formal intervention powers because these powers are an uneasy fit with its hybrid structure and governance arrangements. This finding does not mean that the EBA is incapacitated: rather, the fact that its effectiveness relies more on facilitation than on threats suggests that the EBA is actually well-equipped to make progress in its unifying role.
\end{abstract}

Eilís Ferran: FBA, Professor of Company and Securities Law \& JM Keynes Fellow.

I am grateful to Emilios Avgouleas, Andrea Enria, Corinne Kaufman, Niamh Moloney, Jonathan Zeitlin and participants at a seminar organised by the Edinburgh Centre of Commercial Law for insightful comments on draft versions of this paper. The usual disclaimer applies.

Eilís Ferran

evf1000@cam.ac.uk

1 University of Cambridge, Cambridge, UK 
Keywords Financial regulation $\cdot$ EU · Governance

\section{Introduction}

\subsection{A Milestone?}

The European Banking Authority (EBA) marked 5 years of operation in January $2016 .{ }^{1}$ In terms of simple longevity, 5 years hardly seems like a major milestone in the life of a public body but given the exceptional intensity of the period it has lived through since 2011, the end of the fifth year of its existence is an opportune moment to critically examine the role of the EBA. ${ }^{2}$ With the emphasis in financial regulatory policy shifting from the restoration of stability to the growth agenda, there is a strong sense that a page has turned. ${ }^{3}$ The question now is whether the EBA has put down sufficiently strong roots to be able to adapt effectively and remain relevant. The Chair of the EBA, Andrea Enria, has acknowledged that on the supervisory front his organisation faces an 'existential search' for a 'value-added' contribution. ${ }^{4}$

\subsection{The Changing World: The EBA, the Single Supervisory Mechanism and the Pressure on Scarce Resources in an Age of Austerity}

The nub of the problem for the EBA is the allocation of responsibility for prudential supervision to the European Central Bank (ECB) and the accompanying centralised institutional architecture for resolution, which together are the key elements of European Banking Union (EBU). Within the institutional structure of the Single

\footnotetext{
${ }^{1}$ Regulation (EU) No 1093/2010 of the European Parliament and of the Council of 24 November 2010 establishing a European Supervisory Authority (European Banking Authority), OJ 2010 L331/12 (EBA Regulation). Subsequent measures that amended the EBA Regulation or otherwise affected the way in which the EBA operates include: Regulation (EU) No 1022/2013 of the European Parliament and of the Council of 22 October 2013 as regards the conferral of specific tasks on the ECB, OJ 2013 L287/5; Directive 2014/17/EU of the European Parliament and of the Council of 4 February 2014 on credit agreements for consumers relating to residential immovable property, OJ 2014 L60/34; Council Regulation (EU) No 1024/2013 of 15 October 2013 conferring specific tasks on the European Central Bank concerning policies relating to the prudential supervision of credit institutions, OJ 2013 L287/63 (SSM Regulation); Directive 2014/59/EU of the European Parliament and of the Council of 15 May 2014 establishing a framework for the recovery and resolution of credit institutions and investment firms, OJ 2014 L173/190 (BRRD); and Regulation (EU) No 806/2014 of the European Parliament and of the Council of 15 July 2014 establishing uniform rules and a uniform procedure for the resolution of credit institutions and certain investment firms in the framework of a Single Resolution Mechanism and a Single Resolution Fund, OJ 2014 L225/1 (SRM Regulation).

2 The analysis in this paper relates to the regulatory framework in place at the date of submission (December 2015) but some important later developments are mentioned in the notes. Also reflecting on the significance of the first years of the new arrangements: Moloney (2013). The paper was completed before the UK EU referendum.

${ }^{3}$ European Commission (2015a), which has spawned initiatives with respect to a range of areas including securitisation, prospectuses, venture capital and covered bonds.

${ }^{4}$ House of Lords European Union Committee (2015), at p. 43.
} 
Supervisory Mechanism (SSM), which has been in operation since November 2014, the ECB and the national competent authorities (NCAs) of euro area countries are joined in a supervisory system based on a distribution of responsibilities for the prudential supervision of euro area banks in which the ECB is in overall charge. ${ }^{5}$ The ECB directly supervises the 'significant' entities via joint supervisory teams, which comprise staff from both NCAs and the ECB. ${ }^{6}$ Whilst the NCAs continue to be responsible for the day-to-day supervision of less significant entities, they do so under the oversight and control of the ECB. ${ }^{7}$ The SSM is supported by the Single Resolution Mechanism (SRM), which comprises a centralised decision-making body (Single Resolution Board or SRB) and fund (Single Resolution Fund or SRF).

The shadow of the ECB looms large over the EBA. ${ }^{8}$ Had the option of giving supervisory responsibilities to the ECB - which now self-identifies as 'a perfect and natural home' 9 for the location of responsibility for prudential supervision commanded more support back in 2009, when the first wave of post-crisis institutional reforms was under consideration, ${ }^{10}$ the EBA might never have come into existence at all. Once in place, supervisory institutions can be hard to dislodge but the EBA is unusually vulnerable. Would the EBA be missed if it were gone (a not entirely fanciful scenario given the range of forces that could lead to further dilution of its role in an unstable environment)? In a nutshell, this article will suggest that there is still a valuable job for the EBA to perform but that it is a somewhat different one from projections at the time of its gestation (when there was a vision, supported by the European Parliament, for it eventually to become the frontline supervisor of cross-border systemically significant banks) and so different thinking is required on the right metrics for judging its success or failure. Whereas the EBA and its sister authorities for capital markets (European Securities and Markets Authority - ESMA) and insurance (European Insurance and Occupational Pensions Authority - EIOPA) began in more or less the same place, it has now become clear that they are on different trajectories.

The niche for the EBA to target now is that of being the Single Market 'glue' between the Member States that are participating in the SSM and those that are not. The need for an institution to manage co-existence in order to maintain the integrity of the Single Market stems from the fact that whilst the SSM has the capacity to extend to EU Member States that do not use the euro (and some non-euro Member States, in particular Romania, Bulgaria and Denmark, are exploring the possibility),

\footnotetext{
5 SSM Regulation; Regulation of the ECB of 16 April 2014 establishing the framework for cooperation within the Single Supervisory Mechanism between the ECB and national competent authorities and with national designated authorities (SSM Framework Regulation) (ECB/2014/17), OJ 2014 L 141/51.

${ }^{6}$ ECB (2014), at pp. 9-11; ECB (2015), at pp. 34-37. The ECB directly supervises all institutions that are classified as significant, comprising around 120 groups representing approximately 1200 supervised entities: ECB (2015), at p. 4.

7 Amounting to around 3500 entities: ECB (2015), at p. 4.

8 See, e.g., Brown (2015), where the account of the EU position treats the ECB as the counterpart to ESMA and EIOPA for banking and the EBA is not mentioned. Whilst this account is inaccurate, it serves to make the point about the vulnerability of the EBA to being overlooked.

9 ECB (2015), at p. 4.

${ }^{10}$ de Larosière (2009), paras. 167-172.
} 
the chances of some other non-euro Member States, such as Sweden, deciding to forgo national control of oversight of their banks are small. It is not a novel insight to associate the EBA with this unifying role and, indeed, some changes have already been made to the way in which it operates to accommodate the new reality. However, more reflection is needed to understand fully the implications of the enhanced responsibility for managing co-existence that now falls to the EBA.

An inquiry into the post-SSM EBA has political salience given the well-known threats of Single Market fragmentation (including the UK exit, or so-called 'Brexit' risk $^{11}$ ). There are also very strong practical reasons related to financing and resources to conduct an inquiry that could help to clarify the expectations that surround the EBA. The EBA has found itself in a difficult financial situation. ${ }^{12}$ That the EBA's budget and resources are too constrained for the range of tasks it is expected to perform is widely acknowledged but concrete steps to rectify the problem have not yet been taken. ${ }^{13}$ The EBA asked the European Commission for a budget increase in 2015 but the fraught political negotiations around the entire 2015 EU budget had a sting in the tail for the EBA in that it suffered a $6.2 \%$ cut, which represented a decrease of $15 \%$ compared to the draft 2015 budget that the EBA had submitted at the beginning of 2014. A further problem is that the Commission tightly controls the deployment of resources, thereby depriving the EBA of the flexibility to move budgetary resources to meet immediate needs. ${ }^{14}$ In 2015 , the EBA had to amend its annual work programme in response to resource constraints, including by extending, by up to a year, deadlines on mandates and even by dropping altogether some of the planned deliverables. ${ }^{15}$ Industry financing would be a more robust long-term solution for the EBA's financial plight ${ }^{16}$ but an industry

\footnotetext{
11 At the time of writing continued UK membership of the EU was assumed. Brexit may affect the calculations of other non-euro Member States on the advantages of remaining outside the euro and/or EBU.

12 The EBA's funding comes from mandatory contributions from the national competent authorities for banking and from the central Union budget in a 60/40 split.

13 That funding is not commensurate with the growing list of tasks and responsibilities was one of the key findings in the Commission's review of the ESAs: European Commission (2014), at p. 11. The Council has acknowledged that 'funding arrangements are possibly a more pressing issue than other medium term issues': ECOFIN (2014). Budgetary and resource constraints have also been highlighted in other publications including: European Court of Auditors (2014), at p. 15; IMF (2013a), at p. 11; IMF (2013b), at pp. 10 and 21. The European Parliament has described the EBA's mixed financing arrangement as 'inflexible, burdensome, and a potential threat to its independence': Resolution of the European Parliament of 29 April 2015 with observations forming an integral part of the decision on discharge in respect of the implementation of the budget of the European Banking Authority for the financial year 2013, OJ 2015 L255/206. A study of the European Supervisory Authorities commissioned by the European Parliament by the accountancy firm Mazars also identified funding as a major source of concern: Mazars (2013).

14 Mazars (2013), at pp. 24-26. In the 2015 budget round, EBA received 120 FTE temporary agent posts against the 140 it had requested: EBA (2015a).

15 EBA (2015a, b), at p. 18. EBA has since outlined its 2016 annual work programme and its 2016-2018 multi-annual work programme but both are subject to resource constraints.

16 The industry-funded model is supported in principle by EU institutions: European Commission (2014), at p. 11; European Parliament, Resolution of 29 April 2015, OJ 2015 L255/206.
} 
that has seen the bill for supervision rise significantly since the financial crisis ${ }^{17}$ and which has also been served with new or increased demands for contributions to deposit protection and resolution funds ${ }^{18}$ is unlikely to be sympathetic to calls to pay more without a convincing case that there is a real job to be done and that it is worth paying for. ${ }^{19}$ Greater clarity about its role could also help the EBA to attract well-qualified staff by enabling potential employees to more readily differentiate between the EBA's remit and that of the ECB and to discern which of these bodies best matches their own skills and interests.

The article proceeds as follows. Section 2 suggests that the EBA's quest for relevance in a changing world lies more in building on the start that it has made as a manager of co-existence than in the use of powers to direct the conduct of supervision. The article draws upon governance scholarship to situate this claim within a theoretical framework. Section 3 briefly outlines the EBA's main tasks. This overview sets the scene for a more detailed inquiry into the EBA's operations in key areas: regulatory products (Sect. 4); and oversight, including activities relating to the interpretation and enforcement of the rulebook, efforts to foster the standardisation of supervisory processes, and responsibilities for the organisation of stress tests (Sect. 5). These Sections provide the evidence to support the article's claims about the value that the EBA adds, primarily by acting as a facilitator and manager, to both regulation and supervision for the furtherance of Single Market objectives. Section 6 concludes.

\section{Cutting its Cloth to Suit Reality: Fashioning a Relevant Role for the EBA in a Changing Environment}

\subsection{Where Does the EBA's Future Lie? Working Within its Mandate and Governance Model}

The standard litany of problems currently faced by the EBA includes handicaps resulting from inadequacies in its legal mandate and powers, and inefficiencies in its

\footnotetext{
17 The ECB recovers supervisory expenditures via industry levies: Regulation of the ECB of 22 October 2014 on supervisory fees (ECB/2014/41), OJ 2014 L311/23. These charges are on top of any fees that institutions are required to pay for supervision at the domestic level: Wolfers and Voland (2014), at p. 1479. The SRB is also funded by industry contributions: SRM Regulation, Art. 65. Banks situated outside the euro area have also seen the costs of supervision rise as a result of the post-crisis rise in supervisory intensity: e.g., the UK supervisory budget increased by over $30 \%$ between 2011 and 2013 : Masters (2013).

18 Directive 2014/49/EU of the European Parliament and of the Council on deposit guarantee schemes, OJ 2014 L 173/149, imposes an ex ante industry funding model for deposit guarantee schemes. Under the BRRD and the SRM Regulation, resolution funds are also to be prefunded through industry contributions.

19 Industry already indirectly foots some of the bill for the EBA through fees paid to NCAs but the bill could be expected to increase under direct funding models.
} 
internal governance. Whilst it is indisputable that these are serious issues, the points have been well made already by many informed and influential voices. ${ }^{20}$ The intractable nature of the issues suggests that governance change for the EBA, if it comes at all, will be modest and incremental. For that reason, there is a need also to focus on what the EBA can do within existing structures or with only minor improvements.

The concerns about the EBA's governance and powers stem from its hybrid institutional character. The EBA is an independent EU agency with its own separate legal personality. ${ }^{21}$ It has its own officers and managerial team, staff, office, IT systems and other appurtenances of an established organisation. A Management Board takes decisions on operational matters and is responsible for the implementation of the work programme. ${ }^{22}$ The EBA provides technical support to the Commission and has been given significant intervention powers, which could be used to assist the Commission in its role as guardian of the rulebook. These powers touch the boundaries of legality in EU law. ${ }^{23}$ The Commission has significant influence over the EBA, including the control of its budget, as already discussed. At the same time, the EBA is also an institutionalised network of the micro-prudential banking competent authorities (and national resolution authorities), and its role includes the responsibility to foster convergence and cooperation. The EBA's governance structure, which is headed by a Board of Supervisors in which the heads of the national competent authorities (not including the ECB) are the voting members, reflects its intergovernmental side. ${ }^{24}$ It is thus the national supervisors, acting collectively, that determine the EBA's policies and practices and make the key formal decisions. This hybridity is common in EU agencies ${ }^{25}$ but the issues associated with it appear in a particularly distinctive form in the EBA because of the array of formal powers vested in it by the EU legislature.

Some observers regard the EBA's dependency on national supervisors as a weakness, and it has been called upon to assert its own authority and be more than just a 'club' of supervisors. ${ }^{26}$ However, proponents of this view may be failing to

\footnotetext{
${ }^{20}$ Adam Farkas, EBA's Executive Director has remarked: 'I must admit that some of the obstacles that have come our way are indeed related to our complicated governance structure and to constraints in terms of powers': EBA (2014a), at p. 12. The European Commission has recognised the need to consider certain governance and mandate changes: European Commission (2014). The Special Report by the European Court of Auditors (European Court of Auditors (2014)) also identifies a number of problematic areas.

21 EBA Regulation, Arts. 1 and 5.

22 EBA Regulation, Art. 47. The voting members of the Management Board are the EBA Chair and six other members of the Board of Supervisors: EBA Regulation, Art. 45. The EBA Executive Director and the Commission representative participate in meetings, generally without the right to vote: ibid.

23 This has led to high-profile test cases, including in the banking context: Case C-507/13 United Kingdom v. Parliament and Council, A-G Opinion, 20 November 2014, rejecting the UK's plea of ultra vires with respect to the conferral of power on the EBA to develop technical standards on bankers' bonuses under CRDIV, Art. 94(2). The UK conceded defeat ahead of the final judgment of the Court and did not pursue the challenge further.

24 EBA Regulation, Art. 40.

25 Everson et al. (2014); Everson and Vos (2014).

26 Former EU Commissioner Michel Barnier quoted in House of Lords European Union Committee (2015), at p. 36.
} 
take full account of the SSM's impact on the EBA and thereby setting the EBA an impossible target. On the one hand, the ECB's strong control of the conduct of supervision within the SSM participating Member States should reduce the incidence of situations that give cause for the EBA to consider using its powers to call idiosyncratic supervisors into line or even to override them. The ECB is already actively probing suspected cases of failure to apply EU law correctly. ${ }^{27}$ On the other hand, the EBA is likely to struggle in David and Goliath battles with any of the powerhouses in the new world of EU frontline banking supervision, namely the ECB and the Swedish Financial Supervisory Authority/Riksbank, yet could not credibly pursue a policy of assertiveness by confining its attention to smaller players. ${ }^{28}$ In this environment, to prioritise helping the 'club' to function well could prove to be a far more sensible aspiration for the EBA than a goal of becoming more oriented towards trying to tell a powerful group, including an EU institution, what to do.

To claim that the EBA's prospects for future success may lie more in its role as a manager of co-existence than as a 'director' of supervisors is not to deny the significance of the breakthrough of giving the EBA agency status and equipping it with formal intervention powers, or to call for the reversal of the agencification of this area, which would put the clock back. ${ }^{29}$ Moreover, since social science now offers a mature understanding of the extent to which the organisers of the context in which decisions are made can influence the outcomes, ${ }^{30}$ to doubt the EBA's ability to force outcomes is not to say that the EBA is powerless to change behaviour in more subtle ways. The approach adopted here does not rule out as undesirable governance modifications, such as making the EBA Chair a full voting member of the Board of Supervisors or enhancing the role of its Management Board, to tilt the balance somewhat in favour of a European orientation (although such changes would need to be carefully calibrated so as not to dilute too far the input of those who are in touch with supervision on the ground). ${ }^{31}$ Instead the claim advanced here

\footnotetext{
27 Binham (2015).

28 The balance of power is evident, for example, in the location of responsibility for detailed manuals on the conduct of supervision: the EBA is mandated to set out non-binding supervisory best practices in a Supervisory Handbook but frontline supervisors control the detail and establish binding requirements in their supervisory manuals: EBA Regulation, Art. 8(1)(aa) (inserted by Regulation (EU) No 1022/2013, supra $\mathrm{n}$. 1). On the development of the Handbook: EBA (2015b), at p. 53. On the development of the ECB Supervisory Manual: ECB (2015), at pp. 33-34.

29 Within the EU regulatory space, agencies are viewed as forming the 'second wave' that replaces networks and committees in order to improve the quality and effectiveness of EU regulation: Mathieu (2014). The EBA's history - as the successor to the Committee of European Banking Supervisors, which, in the view of the de Larosière Group, had reached the limits of its effectiveness - is consistent with this view.

30 Thaler and Sunstein (2008).

31 Comparisons can be made with the EBU institutional arrangements in which the executive component is stronger: see the SRB executive session (the SRB Chair and four further full-time members as permanent members and representatives of relevant MSs on an ad hoc basis) in which the executive members make decisions in the absence of consensus: SRM Regulation, Arts. 43(1)(b) and 53-55; and the ECB supervisory board (Chair, Vice-Chair and four ECB representatives as well as representatives of each MS NCA, with all members having voting rights): SSM Regulation, Art. 26. The governance of the IFRS Foundation has also been mentioned as another model from which inspiration could be drawn: Cappiello (2015).
} 
proceeds from the premise that extensive change would face formidable challenges at the political level and locates the search for a meaningful future role for EBA in the advantages that flow from its hybridity. More specifically, the contention is that the accumulated knowledge, understanding and expertise on best practices that the EBA gains from being the hub of an organised network can contribute to better decision-making and can also function as a source of strength that should enable the EBA, itself not a frontline supervisor, to act with more credibility when it does feel the need to take a stronger leadership role, whether that be in sowing the seeds of organic change, in cajoling particular supervisors to follow best practices, or in considering more hard-edged intervention. A view that starts from recognition of the possibilities within the EBA's existing governance and organisational model, whilst not being blind to its limitations, may allow for the setting of more realistic goals, put the intervention powers into perspective and could, over time, shield the EBA from accusations that it is 'toothless' because the intervention powers are little used.

The following sections of this article seek to substantiate the claim that the EBA's quest for relevance in a changing world lies more in building on the start it has made as a manager of co-existence than in being a director of supervisors, but before turning to a detailed testing of this claim in the context of key areas of the EBA's operational activities, it is helpful to place the inquiry within a theoretical framework.

\subsection{Situating the EBA's Quest for Relevance in Governance Scholarship}

The EBA's situation is essentially unique, distinctive even from that of its sister European Supervisory Authorities because of the particular burden that falls on it to help manage the co-existence within the Single Market of the supervisory models of both the Member States that participate in EBU and the non-participating Member States. This makes the EBA especially fascinating from a theoretical perspective.

Uniqueness is not so remarkable in itself because novelty is a characteristic of the EU's multilevel, polycentric governance structure. EU institutional innovation is rooted in the distinctive character of the EU, which forces experimentation in order to adapt institutional models that developed within nation states to work effectively in a more complex supranational environment. The EU's deployment of distinctive and innovative approaches to achieve its objectives has received close attention from scholars interested in new forms of governance. ${ }^{32}$ One strand of the scholarly debate that may further our understanding of the EBA relates to experimentalism. ${ }^{33}$

The literature explains that an experimentalist system is an institutionalised network characterised by recursive learning drawn from fluid, multidirectional relationships between central and local actors in pursuit of common framework

\footnotetext{
32 For a useful overview on new governance: Armstrong and Kilpatrick (2007). Other valuable discussions of new governance in the EU include: Héritier and Lehmkuhl (2008); Armstrong (2011). Specifically addressing commonalities and differences between new governance and experimentalism: de Búrca (2010).

33 This Section draws on the work of Charles Sabel and Jonathan Zeitlin and of other scholars who have taken up the theme, in particular the collections of essays in: Sabel and Zeitlin (2010); Zeitlin (2015). Other recent contributions to the literature include: de Búrca et al. (2013); de Búrca et al. (2014).
} 
goals, information sharing, bottom-up problem solving, monitoring and peer review. An experimentalist system is dynamically adaptive, and its reflexive and iterative character ensures that means and ends are open to revision in the light of implementation experience. Claims made for experimentalist approaches include that they offer the potential for workable solutions in areas that are technically complex and strategically uncertain, where conventional 'top down' approaches may be inferior or simply not possible because there is no more than a thin consensus and details are contested at the political level.

Just a few years ago, EU financial regulation was identified as an area demonstrating patterns of decision-making that could be characterised as experimentalist. ${ }^{34}$ Since then an intense period of reform that has put in place a significantly expanded EU-wide regulatory framework (the 'single rulebook') reinforced the formal powers of supervisors, turned committees of supervisors into the EBA and the other European Supervisory Authorities, and established the ECB as a prudential supervisor within the SSM, has pushed EU financial regulation further in the direction of a traditional hierarchical command and control system. The autonomy of national supervisors and resolution authorities, which are the lower level actors that are seen to play a pivotal role in experimentalist governance, has been reined in, especially within the euro area.

With the avoidance of regulatory arbitrage and the creation of a level playing field in both regulation and supervision being the mantras of the day, an attempt to suggest that it may still be worthwhile to look to experimentalist governance - an approach whose hallmarks include open participation, lack of formal hierarchy, open-ended goals, and extensive deliberation ${ }^{35}$ - as a relevant concept may seem strained. ${ }^{36}$ Certainly it is indisputable that the overall direction of travel for EU financial regulation is away from experimentalist governance in its ideal and most demanding form. However, the EBA occupies a special position. Since experimental governance scholarship is not predisposed to favour the progressive accretion of power to the centre as the preferred outcome, looks beyond traditional notions of regulation based on 'command and control' and does not downplay the merits of systems that depend heavily on local actors, it has promise as a conceptual framework to enrich an understanding of the EBA's role that identifies coordination of co-existence as its core responsibility. An experimentalist-informed analysis one that, as Jonathan Zeitlin has suggested, is sensitive to the possibility of finding 'experimentalist practice flourishing beneath a hierarchical veneer" ${ }^{37}$ - may allow both for a more robust understanding of the situation in which the EBA actually finds itself and for a more nuanced view on desirable adjustments that could improve the EBA's effectiveness and enable it to more fully deliver positive results.

\footnotetext{
34 Posner (2010).

35 de Búrca et al. (2013), at p. 738.

${ }^{36}$ For support for the view that significant traces of experimentalism remain in EU financial governance: Campbell-Verduyn and Porter (2014); Zeitlin (2016).

37 Zeitlin (2016).
} 


\section{The EBA in Action}

The EBA's formal overarching objective is to 'protect the public interest by contributing to the short, medium and long-term stability and effectiveness of the financial system, for the Union economy, its citizens and businesses' ${ }^{38}$ It has a range of responsibilities and tasks in pursuit of this goal. The EBA's principal sphere of activity is prudential regulation and supervision ${ }^{39}$ but its remit has been extended to cover other areas, including, in particular, recovery and resolution. ${ }^{40}$ The two main strands of EBA's work are the production of regulatory 'products' (rules, guidelines and recommendations) and oversight (including interpretation of the single rulebook, scientific analysis, organisation of stress tests, participation in supervisory colleges, investigation of areas of possible supervisory non-compliance, mediation of cross-border supervisory disputes and formal intervention).

\section{Regulatory Products}

\subsection{The EBA's Contribution to the Development of the Single Rulebook in Banking}

The EBA operates within the overall EU framework for EU financial regulation, which is known as the Lamfalussy process. Level 1 of the Lamfalussy process comprises Regulations and Directives ('legislative acts') decided by normal EU legislative mechanisms (usually the ordinary legislative procedure in which the Council and the European Parliament are co-legislators). In pursuit of the goal of a comprehensive single rulebook, it has become the norm for Level 1 measures to give power to the Commission to pass Level 2 measures ('non-legislative acts'). Level 2 measures, which are binding EU rules made by the European Commission, come in two main forms. ${ }^{41}$ The first type of Level 2 measure comprises delegated acts and implementing acts, which are instruments that are both drafted and made by the Commission itself. The second type of Level 2 measure comprises binding technical standards (regulatory technical standards (RTS) and implementing technical standards (ITS)), which are also made by the Commission but where the draft text is written by the relevant European Supervisory Authority and the Commission must justify departures from the draft text. ${ }^{42}$ This second type of Level 2 measure has been developed in the context of EU financial services regulation

\footnotetext{
${ }^{38}$ EBA Regulation, Art. 1(5).

${ }^{39}$ CRDIV; Regulation (EU) No 575/2013 of the European Parliament and of the Council of 26 June 2013 on prudential requirements for credit institutions and investment firms and amending Regulation (EU) No 648/2012, OJ 2013 L176/3 (CRR).

${ }^{40}$ BRRD; SRM Regulation.

${ }^{41}$ TFEU, Art. 290 (delegated acts): a legislative act may delegate to the Commission power to supplement or amend certain non-essential elements of the legislative act; TFEU, Art. 291 (implementing acts): implementing powers can be conferred on the Commission (or in specific cases, the Council) where uniform conditions for implementing legally binding Union acts are needed.

${ }^{42}$ EBA Regulation, Arts. 10-15.
} 
because of the special need for technical input in this field. Level 1 measures specify, on a case-by-case basis, the type of Level 2 measure that the Commission is empowered to adopt. ${ }^{43}$

The EBA's main regulatory responsibility within the EU hierarchy of norms constituted by the Lamfalussy process is to write and to keep under review binding technical standards within its sphere of activity. This is a large and demanding undertaking: the Capital Requirements Regulation (CRR) and the Capital Requirements Directive (CRDIV) contain over 100 mandates for regulatory and implementing technical standards, whilst the Bank Recovery and Resolution Directive (BRRD) adds almost 40 more. By the end of 2014, the EBA had issued 93 technical standards, ${ }^{44}$ and in 2014 alone it delivered 22 regulatory technical standards and 10 implementing technical standards. ${ }^{45}$ As at December 2015, no EBA draft had triggered the formal Commission amendment process, which gives an important empirical indication of the power that it wields notwithstanding that it is only a quasirule-maker. However, there had been instances where the text adopted by the Commission differed in certain respects from the draft submitted by the EBA, which left some interpretative uncertainty. ${ }^{46}$ Textual variations that sit in the grey area between drafting improvement and substantive change (which should have triggered the formal amendment process) hint at a degree of tension in the Commission-EBA dynamic. There could be further strain in the next few years as the EBA struggles, on inadequate resources, to fulfil the single rulebook mandates set by the post-crisis Level 1 legislation. As a last resort, the EBA could seek to pass back to the Commission the responsibility for drafting binding technical standards, a possibility that is catered for in the regulatory framework, ${ }^{47}$ although when adopted it was envisaged more as a mechanism for the Commission to hold the EBA in check than a means for the EBA to shed tasks in order to manage an impossible workload.

Binding technical standards are technical, must not imply strategic decisions or policy choices, and their content and conditions of application are delimited by the legislative acts on which they are based. ${ }^{48}$ Yet first impressions could mislead as to the practical significance of a large and growing body of standards that touch directly on the day-to-day operations of the entire EU banking sector. Whilst some standards are admittedly targeted at standardising reporting procedures and highly specialised

\footnotetext{
43 Moloney (2014a), at pp. 923-925 (discussing the fine distinction between BTS and other Art. 290/291 rules, suggesting that pragmatism may come to govern the choice, and cautioning of risks of legal challenge on grounds of incorrect choice of measure). On the fragility of the Art. 290/291 distinction and associated concerns: Case C-427/12, Commission v. Parliament and Council (Biocides), Judgment 18 March 2014; Ritleng (2015); Craig (2015).

44 EBA (2015b), at p. 8.

45 EBA (2015b), at p. 23. See also CRDIV/CRR RTS and ITS Overview Tables at http://ec.europa.eu/ finance/bank/regcapital/acts/index_en.htm. Accessed 1 December 2015.

46 E.g., Commission Delegated Regulation (EU) No 604/2014 of 4 March 2014 supplementing Directive 2013/36/EU of the European Parliament and of the Council with regard to regulatory technical standards with respect to qualitative and appropriate quantitative criteria to identify categories of staff whose professional activities have a material impact on an institution's risk profile, OJ 2014 L167/30, Art. 4(1)(c), and Single Rulebook Q\&A, Q2014_1321.

47 EBA Regulation, Arts. 10(3) and 15(3).

48 EBA Regulation, Arts. 10(1) and 15(1).
} 
matters, ${ }^{49}$ others have considerable impact. The regulatory technical standards in two key areas - own funds (under the CRR), ${ }^{50}$ and the so-called MREL, which relates to minimum holdings of own funds and liabilities eligible for bail-in (under the BRRD) ${ }^{51}$ - stand out as instances where a seemingly highly technical role - being in de facto control of the definitions that determine the scope of regulatory criteria - has material implications for banks in terms of dictating potentially costly changes in banks' liability structures and higher costs of funding, This, in turn, will impact on the real economy to the extent that banks respond to a more demanding regulatory capital environment by modifying their lending practices. ${ }^{52}$ According to some claims, the EBA's proposed approach to one aspect of the MREL framework - contractual recognition in contracts governed by third-country laws under Article 55 of the BRRD - had the potential to disturb many tens of thousands of contractual relationships. ${ }^{53}$ Another pertinent example is the EBA's role in setting the methodology for the identification of global systemically important institutions, a classification that triggers more stringent regulatory requirements. ${ }^{54}$ The controversy that surrounded the regulatory technical standard to define material risk takers for the purposes of the bankers' bonus restrictions in the CRDIV, in particular with respect to the setting of the $€ 500,000$ quantitative threshold, gave a powerful demonstration of the industry's assessment of the significance of the EBA's rule-writing powers. ${ }^{55}$

Furthermore, the EBA's influence over EU regulation extends far beyond its formal role in the drafting of binding technical standards. The EBA functions as an important channel for data drawn from experience of rules in action to be fed through to the Commission. The EBA's founding instrument equips it with a range of powers to provide opinions ${ }^{56}$ and reports ${ }^{57}$; and, in addition, various provisions in

\footnotetext{
49 Technical standards, guidelines and recommendations relating to supervisory reporting are listed at http://www.eba.europa.eu/regulation-and-policy/supervisory-reporting. Accessed 1 December 2015.

50 Commission Delegated Regulation (EU) No 241/2014 of 7 January 2014, OJ 2014 L/74; Commission Delegated Regulation (EU) No 2015/850 of 30 January 2015 amending Delegated Regulation (EU) No 241/2014, OJ 2015 L/135; Commission Delegated Regulation (EU) No 2015/923 of 11 March 2015 amending Delegated Regulation (EU) No 241/2014, OJ 2015 L150/1.

51 EBA Final Draft Regulatory Technical Standards on criteria for determining the minimum requirement for own funds and eligible liabilities under Directive 2014/59/EU (EBA/RTS/2015/05).

52 Banking Stakeholder Group (2015).

53 European Banking Federation (2015). See now EBA Draft Regulatory Technical Standards on the contractual recognition of write-down and conversion powers under Article 55(3) of Directive 2014/59/ EU (EBA/RTS/2015/06). The EBA clarified the drafting in certain respects (e.g., with respect to the treatment of secured liabilities) whilst noting that it had to operate within the four corners of Level 1 text and thus could not provide for additional exclusions.

54 Commission Delegated Regulation (EU) No 1222/2014 of 8 October 2014, OJ 2014 L330/27.

55 Commission Delegated Regulation (EU) No 604/2014 of 4 March 2014, OJ 2014 L167/30.

56 EBA Regulation, Art. 8 (EBA opinions to Union institutions to contribute to the establishment of highquality common regulatory and supervisory standards and practices); Art. 29(1)(a) (EBA opinions to competent authorities); Art. 30 (EBA opinions to the Commission where the peer review or any other information acquired in carrying out its tasks shows that a legislative initiative is necessary to ensure the further harmonisation of prudential rules); Art. 34 (EBA opinions to the European Parliament, the Council and the Commission on all issues related to its area of competence).
}

57 EBA Regulation, Art. 9 (EBA reports on consumer trends); Art. 32 (EBA reports on risks and vulnerabilities in its area of competence). 
substantive banking regulation specifically mandate or sanction EBA involvement. ${ }^{58}$ As a result, the Commission relies heavily on the EBA's expertise throughout Level 2 processes. The process surrounding the first two Commission delegated acts under the CRR indicates how embedded the EBA is throughout Level 2: the EBA's analytical report that institutions were interpreting the CRR text on the leverage ratio in different ways was the trigger for the Commission to put forward a delegated act to provide clarification ${ }^{59}$; and, as required by the CRR, the Commission took account of the EBA's reports on the definitions of high-quality assets and on the likely impact of liquidity requirements in drawing up the delegated act that introduced the liquidity coverage ratio. ${ }^{60}$ Examples of the EBA's involvement in Level 2 work can also be drawn from the BRRD context where the Commission mandated the EBA to provide advice for delegated acts across a range of issues, including with regard to the definitions of 'critical functions' and 'core business lines', the exclusion of certain liabilities from bail-in, and contributions to resolution funds. ${ }^{61}$

The EBA is also able to make a significant contribution to the preparatory phase $^{62}$ for Level 1 measures by providing reports, reviews, advice and guidance, either on its own or, as exemplified by work on the regulation of benchmarks, in collaboration with its sister Authorities. ${ }^{63}$ EU financial regulation displays an inbuilt experimentalist tendency insofar as periodic review is built into all of the key sectoral Level 1 measures; the EBA has a designated role in these review processes. ${ }^{64}$ For example, under the CRDIV, the Commission must involve the EBA in the consideration of reforms to the EU's regulatory stance with respect to globally

\footnotetext{
58 E.g., CRR, Art. 459 (imposition of stricter prudential requirements); CRR, Art. 461 (review of phasing-in of liquidity coverage requirements).

59 Commission Delegated Regulation (EU) 2015/62 of 10 October 2014, OJ 2015 L11/37, mandated by Regulation (EU) No 575/2013, Art. 456(1)(j).

${ }^{60}$ Commission Delegated Regulation (EU) 2015/61 of 10 October 2014, OJ 2015 L11/1, mandated by CRR, Art. 460. The Commission cited Union specificities to explain its decision not to follow the EBA's views to the letter: Commission Staff Working Document Impact Assessment SWD(2014) 349 final. Under CRR, Art. 509, the EBA monitors and reports to the Commission the impact of the liquidity coverage ratio: EBA (2014c). The EBA has described this work as functioning as a 'basis' for EU policy makers in their work on high-quality securitisation in the EU. But the 2015 report was a victim of the budget cuts: EBA (2015a).

61 EBA (2014b). See also EBA (2015b), at pp. 46-47.

62 The EBA's Level 1 involvement falls away after legislative proposals enter the political phase. There is untapped potential in this area, for example, to improve the efficiency of the Level 1/Level 2 interface by involving the EBA in defining mandates and in setting realistic deadlines: EBA (2014a), at p. 9; European Court of Auditors (2014), at p. 23; ECOFIN (2014); House of Lords European Union Committee (2015), at pp. 37-38. But the Commission notes that the ESAs are distinct from European institutions and that their role in regulatory processes therefore has to be assessed within Treaty limits: European Commission (2014), at p. 5.

63 The joint ESMA, EBA, EIOPA letter of 7 March 2013 to the Commission outlining a possible framework for the regulation of the production and use of indices serving as benchmarks in financial and other contracts was part of a process, also involving the development of ESMA-EBA Principles for Benchmarks (2013), that led to a Commission proposal for a new Regulation (COM(2013) 641 final). Trilogue discussions on this proposal reached agreement in November 2015: European Commission (2015b).

64 CRR Arts. 502-519; CRDIV, Art. 161; BRRD, Art. 129.
} 
systemically important institutions ${ }^{65}$ and must also work closely with the EBA in reviewing the EU's regulatory stance on remuneration, on the monitoring of diversity practices within banks, and in the evolution of EU law with respect to Islamic finance. ${ }^{66}$ But the EBA's ability to shape Level 1 thinking is not confined to formal periodic reviews and specific mandates as it can also act on its own initiative.

The EBA can highlight areas where existing law is in need of clarification and, in suitably circumspect terms that are attuned to institutional sensitivities with respect to the right of legislative initiative, can suggest ways in which the law could evolve. ${ }^{67}$ An illustration of the EBA taking the lead in building the case for a legislative initiative is provided by its consultation on new guidelines relating to the CRDIV remuneration framework: the EBA highlighted the limits of the proportionality principle as a basis for exempting smaller institutions from some of the requirements and called upon interested parties to provide input on this matter. ${ }^{68}$ The EBA then used the responses to this consultation to develop an Opinion addressed to the European Commission, European Parliament and Council in which it suggested legislative amendments that would allow for a broader application of the proportionality principle. ${ }^{69}$ Admittedly, this rather laboured procedure is nowhere near the streamlined fast-track amendment process that is missing from EU financial regulation, ${ }^{70}$ but this aside does not detract from the substantive point about the EBA's growing capacity to influence the reform agenda.

The EBA's ubiquity in the regulatory and quasi-regulatory sphere is further reinforced by its power to issue guidelines and general recommendations. Specific provisions within sectoral banking and resolution legislation require the EBA to issue guidelines on particular matters but it can also issue guidelines and recommendations under its own initiative in areas that fall within the scope of its activity. ${ }^{71}$ The general source of this power is Article 16 of the EBA's founding instrument, which provides for the EBA to issue guidelines and recommendations with a view to establishing consistent, efficient and effective supervisory practices, and to ensure the common, uniform and consistent application of Union law. The Article 16 twin objectives to promote supervisory consistency and to ensure the proper application of the law mean that the EBA cannot use guidelines to encroach on as yet unregulated territory, although work on guidelines may pave the way for

\footnotetext{
65 CRDIV, Art. 132.

66 CRDIV, Art. 161.

67 E.g., EBA Opinion on lending-based crowdfunding (EBA/Op/2015/03) recommending clarification and putting forward proposals for regulatory measures 'should EU legislators consider developing a possible regulatory framework'; EBA Opinion on mortgage lending value (MLV) (EBA/Op/2015/17) (identifying problems in the application of an RTS in the valuation of covered bond collateral and advising the Commission to initiate appropriate legislative steps to amend the CRR).

68 EBA, Consultation on guidelines on sound remuneration policies (EBA/CP/2015/3). The final guidelines were published in December 2015 (EBA/GL/2015/22). See also infra n. 97.

69 EBA, Opinion on the application of the principle of proportionality to the remuneration provisions in Directive 2013/36/EU (EBA/Op/2015/25).

${ }^{70}$ House of Lords European Union Committee (2015), at pp. 40-41, 44-45.

71 As noted in the BRRD, Recital 115. See also European Court of Auditors (2014), at p. 58.
} 
more formal intervention at a later stage. ${ }^{72}$ The limits of the EBA's Article 16 power matter, because whilst such guidelines and recommendations are not formally binding, financial institutions and competent authorities ${ }^{73}$ are expected to make every effort to comply, and this expectation is supported by a 'comply or explain' mechanism whereby competent authorities must confirm compliance or give reasons for non-compliance. ${ }^{74}$ Compliance tables are published and reported on in the EBA's Annual Report. ${ }^{75}$ Guidelines may also acquire an enhanced de facto status by being taken into account in the interpretation of binding EU law. ${ }^{76}$

The EBA guidelines for common procedures and methodologies for the supervisory review and evaluation process (SREP), as required by the CRDIV, provide a powerful indication of the practical significance of the EBA's guidance issuance powers. ${ }^{77}$ The SREP guidelines, which now extend to over 200 pages, broaden the focus of the SREP from capital risk and adequacy to a much more comprehensive assessment of a bank's business and risk profile, including financial resources, governance and controls. The expected 'observable effect' of the SREP guidelines is that 'institutions with similar risk profiles, business models and geographic exposures are reviewed and assessed by competent authorities consistently and subject to broadly consistent supervisory expectations, actions and measures, where applicable, including institution-specific prudential requirements'. 78

\subsection{Regulatory Products and the EBA's Working Methods: Making the Most of Hybridity}

The selective overview of the EBA's work on regulatory products in the Section above is intended to substantiate the assertion that the EBA has established its usefulness on the regulatory side. To connect the analysis of the EBA's impact in

\footnotetext{
72 The Commission maintains that the objectives are to be read cumulatively: European Commission (2014), at p. 5. Compare the standard wording in the EBA guidelines that 'guidelines set out the EBA's view of appropriate supervisory practices within the European System of Financial Supervision or [emphasis added] of how Union law should be applied in a particular area'. The EBA's work on guidelines on exposures to shadow banking entities (EBA/CP/2015/6), mandated by CRR, Art. 395(2), is a case where the guidelines are expected to play a role in informing the Commission's own work on possible future legislative proposals: EBA/CP/2015/6, at p. 5.

73 For the purposes of the EBA Regulation, national resolution authorities and the Single Resolution Board are also 'competent authorities': EBA Regulation, Art. 4(2)(iv), as are the Council and the Commission when taking decisions under SRM Regulation, Art. 18, except where they exercise discretionary powers or make policy choices. The ECB in its supervisory capacity is also a competent authority for the purposes of the EBA Regulation: Art. 4(2)(1).

74 The 'comply or explain' mechanism could be extended to financial institutions: EBA Regulation, Art. 16(3).

75 See EBA (2014a), at p. 79; EBA (2015b), at p. 110.

76 SV Capital OÜ v. EBA, Decision of the Board of Appeal of the European Supervisory Authorities, BoA 2013-08.

77 EBA, Guidelines on common procedures and methodologies for SREP (EBA/GL/2014/13); CRDIV, Art. 107 and EBA Regulation, Art. 20a.

78 EBA Guidelines on common procedures and methodologies for SREP, supra n. 77, at p. 9.
} 
the regulatory sphere with the claim that the key to the EBA's future may lie mostly in its role as a facilitator and manager, it is necessary now to attempt to get inside the 'black box' of EBA internal decision-making. This reveals that the EBA does not, and cannot, impose 'its' view against the collective view of the national competent authorities. Rather, their (majority) view is its view.

Regulatory products are made by means of a decision of the Board of Supervisors on the basis of quality majority voting (QMV). ${ }^{79}$ An additional, post-SSM, gloss is that the majority must include a simple majority of SSM participating Member States and of non-participating Member States. ${ }^{80}$ Only the representatives of the Member States have voting rights. But much happens before the step of formal adoption. ${ }^{81}$ The EBA is less transparent about its working methods than its sister Authority, the ESMA, but it is known that it operates through standing committees and working groups comprised of both representatives of NCAs and EBA staff. ${ }^{82}$ The EBA explains that all 'deliverables' are discussed in technical working groups and standing committees where national authorities can provide inputs. ${ }^{83}$ The formal adoption of policies and practices by the EBA's Board of Supervisors is thus not an exercise in rubber-stamping the work of the EBA staff; rather, national supervisors play an integral role throughout the policy formation process.

Concerns have been expressed about the extent of the EBA's dependency on national supervisors. ${ }^{84}$ However, going back to basic thinking on the distribution of responsibilities within a regulatory system and taking account of experimentalist thinking on the merits of a 'bottom up' approach, there is much that is positive about the EBA's work being strongly shaped by the knowledge and experience of frontline supervisors. The direct involvement of actual supervisors in the detailed development of pan-EU regulation and supervisory practices is precisely why the EBA can credibly claim to be an 'actor in close contact with and knowing best the daily functioning of financial markets' ${ }^{85}$ At a fundamental level, this is a strength, not a weakness. (The real illogicality of the current arrangements is that the ECB is not a voting member despite having taken over operational responsibility for supervision within the area of the SSM, a compromise reflecting Council sensitivities $^{86}$ that will one day surely need to be revisited.) This point is worth emphasising because however strong the case for a stronger 'executive' dimension

\footnotetext{
79 EBA Regulation, Art. 44.

80 Ibid.

81 EBA Decision adopting a Procedure for developing and adopting Draft Technical Standards and Guidelines and Recommendations (EBA DC 30, 25 September 2012).

82 IMF (2013b), at p. 11 (reporting four standing committees (Regulation and Policy; Oversight and Practices; Accounting and Auditing; Financial Innovation) and 20 sub-groups). See also Mazars (2013), at pp. 61-62. Consumer protection has since been added to the remit of the Financial Innovation Standing Committee, and a Resolution Standing Committee (note BRRD, Art. 127) has been established.

83 EBA working process, as explained at http://www.eba.europa.eu/about-us/organisation. Accessed 1 December 2015.

84 IMF (2013b), at p. 11.

85 EBA Regulation, Recital 23.

86 ECOFIN (2014) notes the governance issues but stresses the need for a 'careful balance' and to have regard to the 'expertise provided by the national competent authorities'.
} 
to the EBA's operations (and it is certainly strongly supported by informed opinion), care is needed to ensure that organisational change does not inadvertently dilute existing strengths.

Concerns about the role of national supervisors within the EBA relate to the risk of distortions to protect national interests impeding the development of a truly panEuropean view. According to the EBA's founding instrument, the members of the Board of Supervisors are required to 'act independently and objectively in the sole interest of the Union as a whole' and they must not 'seek or take instructions' from their government or public or private bodies. ${ }^{87}$ However, there is evidence to the contrary. ${ }^{88}$ But to expect national supervisors to leave national interests outside the room can only ever be an aspirational standard - a reality that was implicitly recognised in the SSM-related modifications of the EBA voting mechanism to address concerns about the marginalisation of the views of non-participating Member States. These modifications were designed as a response to concerns that the views of participating Member States will coalesce around the ECB's preferences and will result in a powerful caucus at the EBA table. ${ }^{89}$ (Other outcomes, such as the EBA becoming a setting in which tensions between the ECB and national authorities of participating Member States are played out, are also possible but are beyond the scope of this article. As noted above, the logical solution would be for the ECB to be a voting member, perhaps eventually to the exclusion of the Member State competent authorities.)

If the EBA were 'just' the mouthpiece of an informally constituted and rather secretive 'club' of supervisors, the enduring influence of national interests in processes that can so materially shape EU financial regulation would be disquieting. But this characterisation of the EBA is not apt. As an EU agency, the EBA is required to operate within a framework that legitimises the allocation of significant power by demanding formalised consultation and other procedures, transparency and accountability. ${ }^{90}$ Deliberations within the EBA are informed by a myriad of views beyond those of EU prudential supervisors, including those of its sister

\footnotetext{
87 EBA Regulation, Art. 42.

88 European Court of Auditors (2014), at p. 25. Mazars (2013), at pp. 34-35, also discusses the point but notes that there is neither a fixed nor binary distinction between the national and European interest. In its review of all three European Supervisory Authorities, the European Commission acknowledged that the predominant role of the representatives of NCAs in the decision-making process had given rise to some criticism, in particular, that concerns prevailed that national views rather than EU-wide interests dominated: European Commission (2014), at p. 9.

89 The ECB does not appear to see any need for circumspection about its ability to influence policy formation: ECB (2015), at p. 61 ('The ECB strongly influences regulatory debates through its active participation in European and international fora. The Supervisory Policies Division follows and actively contributes to the international regulatory and supervisory agenda and coordinates the SSM positions regarding internal and international policies, drawing on practical supervisory experience.').

90 The EBA has published procedures for the adoption of technical standards, guidelines and recommendations (EBA DC 30), and a public statement on its consultation practices (EBA BS 2012 182(II) (EBA DC 57-Annex 1)). Another relevant publicly available legal documents on processes and procedures is the EBA Code of Good Administrative Behaviour (EBA DC 6, 2011). EBA is accountable to the European Parliament and Council (EBA Regulation, Art. 3) and has a suite of reporting obligations including annual reporting requirements (EBA Regulation, Art. 43(5)).
} 
Authorities, ${ }^{91}$ its Stakeholder Group, ${ }^{92}$ the respondents to its public consultations, and the bodies with which it interacts in its international activities. ${ }^{93}$ The Commission, a non-voting member of the Board of Supervisors, has considerable influence. ${ }^{94}$ Furthermore, the EBA's decisions are subject to challenge, both before the Joint Board of Appeal of the European Supervisory Authorities ${ }^{95}$ and in actions before the Court of Justice of the EU. ${ }^{96}$

Is it plausible, then, to regard this system as a broadly functional combination of some of the strengths of an open-textured approach with experimentalist traits (in particular, participative decision-making in which actors responsible for implementation at the local level have a central role, and a dynamic regulatory framework in which periodic review and adjustment in the light of 'on the ground' experience is embedded in principle - if not yet adequately supported by an efficient amendment process) with the disciplines and efficiencies of an administrative agency operating within an established EU framework? There are encouraging signs: in terms of quantity and timeliness, the production line has been healthy (although at the EBA level some tight deadlines have had to give way in the face of resource limitations, and further delays at Commission level hint at behind-thescenes tensions in the endorsement process); and the emergence of EBA products that take a position inconsistent with the views of a prominent supervisor is an auspicious indication that controversies are not being ducked. ${ }^{97}$ An obvious potential weakness is that the system is at risk of being paralysed by disagreements among supervisors, but, as well as QMV, there is what experimentalists label a 'penalty default mechanism' in the form of the Commission's ability to step in should the EBA production process break down or produce 'outlandish" ${ }^{98}$ results. 99 Penalty defaults are said to operate as a safeguard by inducing 'appreciation of the relative benefits of joint efforts by sanctioning non-cooperation, typically by substantially reducing the parties' control over their fate through the imposition of

\footnotetext{
91 Including via the Joint Committee of the Authorities (EBA Regulation, Art. 54).

92 EBA Regulation, Art. 37.

93 EBA Regulation, Art. 33.

94 Mazars (2013), at p. 34.

95 EBA Regulation, Art. 60.

96 EBA Regulation, Art. 61.

97 E.g., EBA Opinion on the application of Directive 2013/36/EU (Capital Requirements Directive) regarding the principles on remuneration policies of credit institutions and investment firms and the use of allowances (EBA/Op/2014/10); EBA Consultation on guidelines on sound remuneration policies (EBA/ CP/2015/03), mandated by CRDIV, Arts. 74-75. This sustained pressure challenged the UK Prudential Regulation Authority's views on the treatment of 'allowances' and was effective to change practice: EBA Follow-up Report on the actions taken by competent authorities following the publication of the Opinion of the European Banking Authority on the application of Directive 2013/36/EU regarding the principles on remuneration policies for credit institutions and investment firms and the use of allowances (November 2015).

98 Tröger (2014), at p. 487.

99 As noted earlier, EBA Regulation, Arts. 10 and 15 both make provision for the Commission to adopt standards without an EBA draft after deadlines have passed. They also cater for non-endorsement or amendment of EBA drafts by the Commission.
} 
an alternative, less attractive regime or outcome that none of them favors' ${ }^{100}$ No doubt the task of managing a complex system that depends heavily on finding common ground between multiple actors whose preferences remain heterogeneous in many respects and which has been further complicated by the post-SSM division of those actors into two main sub-groups, must be immensely challenging. Outsiders can only speculate about the severity and frequency of clashes of views behind closed doors within the Board of Supervisors. In situations where supervisors initially disagree, the demands on the EBA staff, in terms of both the technical competence to cut through complex issues in an authoritative fashion and the degree of tact and diplomacy to negotiate solutions, must be intense. Yet in spite of the difficulties, ways forward that strike an 'effective balance' ${ }^{101}$ have been found.

\section{Oversight}

\subsection{Shifting the Emphasis from Regulation to Supervision}

This is the point to recall that it was the supervisory side that the EBA Chair, Andrea Enria, had in mind in particular when he referred to his organisation's existential search. The EBA's overall contribution to supervisory convergence has been described as 'relatively limited ${ }^{102}$ and this has been linked to the fact that it operates more as a facilitator and coordinator than as a body that is able to assert directive authority in a hierarchical fashion. ${ }^{103}$ However, there is nothing intrinsically wrong with the EBA working more through facilitation than direction. It is also reasonable to maintain that the fact that the EBA has not made as much progress in supervision as some might have expected is at least as much to do with the distorting effects of the extraordinary demands on the regulatory side as other factors. Whilst regulatory work has dominated thus far, as the single rulebook becomes more complete (and barring an unanticipated new regulatory push on the banking side from the EU institutions - which seems unlikely given the switch of emphasis to strengthening capital markets to reduce the dependency on bank-based finance and to diversify sources of finance for the real economy ${ }^{104}$ ), the EBA should be in a position to concentrate more of its effort (and resources) on supervision. How will the EBA rise to this challenge given its distinctive hybrid character and governance model? The evidence from its contribution on the supervisory side so far provides pointers that are consistent with the overarching claim of this article: that the EBA does have a meaningful future on the supervisory side but the potential for impact lies more in support and facilitation than in direct confrontation.

\footnotetext{
100 de Búrca et al. (2014).

101 Mazars (2013), at p. 14.

102 European Court of Auditors (2014), at p. 37.

103 Ibid.

104 European Commission (2015a), at p. 6.
} 


\subsection{Interpreting the Rulebook}

For the EBA to function as an interpretative mechanism is a logical and valueenhancing complement to its role in the making of regulatory products. Inconsistent interpretation by different authorities is notorious for its corrosive effect on supposedly harmonised cross-border standards. Whilst some degrees removed from formal adjudication, an interpretative mechanism may have considerable de facto constitutive effects. The EBA has made a start in this regard through the establishment of its Single Rulebook Q\&A tool. The Q\&A tool is a centralised function for supervisory authorities, financial institutions and others to put to EBA staff questions relating to the CRDIV, CRR, BRRD and associated technical standards and guidelines. ${ }^{105}$ The process of responding to these questions entails close interaction between the EBA staff and the Commission, and on matters of particular significance the Directorate General Financial Stability, Financial Services and Capital Markets Union will itself prepare answers. ${ }^{106}$ The close interaction between the EBA and the Commission may help to reinforce the status of the EBA's Q\&A tool vis-à-vis the complementary tool maintained by the ECB for the SSM. ${ }^{107}$

The Q\&A tool is an example of the EBA moving in the direction of telling supervisors (and others) what to do, but a degree of coercive authority is not ruled out by the central claim of this paper that the EBA's future may lie more in managing coexistence through facilitation and support than in the assertion of directive authority. The EU single rulebook is a hard-law system, and part of the EBA's complex hybridity is that it has a role, ancillary to that of the Commission, in 'enforcing' adherence. Nevertheless, it is still possible to maintain that a quest for a meaningful future role for the EBA that is concentrated on formal ex post enforcement is unlikely to be particularly fruitful. On the spectrum of 'enforcement' strategies, a repository of learning that aims to avoid problems by pointing authorities and firms to the correct interpretation of the rules is a very mild form of intervention.

\section{3 'Enforcing' the Rulebook}

Consider the case of a national competent authority that has adopted an interpretation of EU law with which the EBA's legal and policy staff, backed by the Commission, disagree. What could the EBA do? One option would for the EBA, prompted by a suitable question, to address the issue through its Single Rulebook Q\&A mechanism. Another option would be for the EBA, working through its Board of Supervisors, to issue an opinion, as it has done, for example, on the compatibility with the CRDIV bankers' bonus restrictions of the practice, which was previously sanctioned by the UK Prudential Regulation Authority, of treating 'role-based' allowances as part of fixed remuneration. The use of the Q\&A mechanism and the

\footnotetext{
105 EBA Regulation, Art. 29(2) provides the legal backing by empowering the EBA to develop new practical instruments and convergence tools to promote common supervisory approaches and practices. 106 EBA, Additional background and guidance for asking questions, available at https://www.eba.europa. eu/single-rule-book-qa. Accessed 1 December 2015.

107 ECB (2015), at p. 61.
} 
issuance of opinions may be layers in a gradually escalating and iterative process of policy formation that later involves other steps, such as the issuance of new or extended Article 16 guidance, as has occurred with respect to bankers' bonuses, ${ }^{108}$ or advice to the EU institutions on the possible need for a review of Level 1 or Level 2 texts. The EBA could also draw attention to practices that do not appear to be consistent with the law, as it has done, for example, in the area of administrative penalties. ${ }^{109}$ But what if none of this fixes the problem?

\subsection{Enforcing the Rulebook: Intervention Powers}

When the EBA and its sister Authorities were established, much attention focused on their new intervention powers, especially the power to investigate alleged breaches of EU law by competent authorities and, in certain circumstances, to impose a decision on financial institutions ${ }^{110}$; and the power to mediate and, ultimately, to take a decision with binding effect in cross-border situations where competent authorities disagree about the procedure or content of supervisory action (or inaction). ${ }^{111}$ These powers were among the most striking feature of the upgrade from the old committee-based arrangements and appeared to signify the emergence of EU-level bodies with real teeth.

For the EBA to have the power to override competent authorities (including the ECB) creates a hierarchical structure that, on paper at least, is at odds with models infused with experimentalism. Does the existence of these powers therefore reveal as misconceived the claim that experimentalism, which emphasises lack of hierarchy, can help in efforts to understand the EBA and to identify a useful role for it? Experience so far suggests not. Regulation in action (i.e., supervision) often diverges from regulation on paper, and 5 years on, there is little to suggest that the intervention powers are becoming the touchstone of how the EBA actually functions.

So far as the Article 17 power is concerned, whilst there have been a number of investigations, by the end of December 2015 only one had led to a known formal recommendation. ${ }^{112}$ Moreover, the EBA has erred on the side of caution in its

\footnotetext{
108 EBA CP/2015/3. These guidelines were finalised in December 2015 (EBA/GL/2015/22). On the 'launchpad' effect of Q\&As: Moloney (2014a), at pp. 934-937.

109 EBA (2015c).

110 EBA Regulation, Art. 17. The EBA can make a recommendation to a competent authority, which, if not complied with, can lead to a formal opinion from the Commission and then to enforcement action by the Commission and/or a decision by the EBA addressed to (a) financial institution(s).

111 EBA Regulation, Art. 19. The power to take action in emergency circumstances (Art. 18) was also much discussed and it was politically contentious. However, this article does not examine the Article 18 power because it may already have become a dead letter. If the circumstances of the euro area crisis were insufficiently grave to trigger the use of this power, it is questionable whether this would ever be a live issue.

112 EBA (2015b), at p. 51 (addressed to the Bulgarian National Bank and Bulgarian Deposit Insurance Fund in respect of the treatment of depositors). Investigations into alleged breaches of EU law have been the trigger for a few non-binding mediation cases: European Court of Auditors (2014), at p. 28. See also Mazars (2013), at pp. 67-68. And contrast ECB experience, where between 4 November 2014 and the beginning of 2015, 11 breach reports were received and three were found to be relevant to the ECB's supervisory tasks: ECB (2015), at p. 65.
} 
interpretation of the scope of the Article 17 power. ${ }^{113}$ It has stressed that as a small organisation it does not have the capacity to investigate all complaints. ${ }^{114}$ It has cited reliance on the views of a national supervisor to explain its decision not to use its own-initiative investigation powers. ${ }^{15}$ Setting priorities in order not to be swamped by an unmanageable number of claims is an issue for all investigatory and enforcement agencies. Moreover, the 'enforcement pyramid' of gradual escalation in the force of intervention is a standard feature of regulatory and supervisory practice. Nevertheless, the EBA track record does not suggest an intervention-hungry body. Indeed a preference for alternative mechanisms is evident on the face of the relevant rules of procedure, which include, as a 'negative investigation factor', that the request is more suitable to be addressed by other means, such as peer review or mediation.

It is also becoming clear that use of the EBA's Article 19 binding mediation power is likely to be rather exceptional. The power is subject to tight constraints: (1) the EBA can act only where there is specific legislative provision for it to do so; (2) at least one of the supervisors concerned must ask the EBA to become involved; but (3) as a qualification to (2), the EBA can take up the matter on its own initiative where the specific legislative provision in question permits and 'on the basis of objective criteria, disagreement between competent authorities can be determined'. ${ }^{116}$ The EBA's Article 19 power is, arguably, further constrained by being limited to disagreements on points of law and not extending to disputes concerning the exercise of discretionary judgment. ${ }^{117}$ This is an issue of particular sensitivity in the banking context, where often 'enforcement' may be less about the imposition of a sanction to correct an irregularity than a supervisory 'Pillar $2^{\prime}$ judgment that an institution must hold additional capital. By the end of December 2015 there had been only two known requests to the EBA for binding mediation, ${ }^{118}$ and no known case where the EBA had sought to use its own-initiative Article 19 powers, which, in any case, have been conferred sparingly. ${ }^{119}$ A factor identified by the European Commission in its review of the EBA and the other European Supervisory Authorities as to why binding mediation by the EBA has not taken off was lack of clarity in the founding Regulations as to the scope of and triggers for binding mediation. ${ }^{120}$ This is a matter that could be clarified by appropriate legislative amendments. ${ }^{121}$ More intractable are the issues arising from the concern, also reported by the Commission, that 'the current governance structure of the ESAs [European Supervisory Authorities]... does not favour decisions or proceeding against national authorities'. ${ }^{122}$

\footnotetext{
113 SV Capital OÜ v. EBA BoA 2013-008.

114 Ibid, para. 30.

115 SV Capital Ö̈ v. EBA BoA, 2014-C1-02.

116 EBA Regulation, Art. 19(1).

117 This view derives support from EBA Regulation, Recital 32, but it is controversial. See further Moloney (2014b), at p. 1668.

118 European Court of Auditors (2014), at p. 61; EBA (2015d), at p. 21. EBA (2015b), at p. 56, reports that two Article 19 cases were settled amicably at or before the conciliation stage.

119 CRDIV, Arts. 41, 43, 50, 112, 116 and 117.

120 European Commission (2014), at p. 7.

121 This is on the Commission's agenda: ibid.

122 Ibid.
} 
The EBA's internal rules of procedure give the EBA officers and staff, in particular, the Chair, an important role in both Article 17 and Article 19 processes, especially at the early stages. The Article 17 rules of procedure give the EBA Chair the authority to initiate investigations into alleged breaches of EU law and to close requests without opening investigations, and the responsibility for the conduct of investigations. ${ }^{123}$ The Chair is to be advised throughout by the EBA's legal and policy staff. The Article 19 rules of procedure also confer a gatekeeper role on the EBA Chair and empower the Chair to act as a mediator to facilitate agreement among the parties during the conciliation phase. ${ }^{124}$ However, the scope for EBA officers and staff to assert their own authority is limited because the ultimate decision-making body for Article 17 and Article 19 purposes is the Board of Supervisors. ${ }^{125}$ The powers that the EBA Chair is given by the rules of procedure derive from delegation by the Board of Supervisors. The panels that prepare the decisions for the Board are also composed of representatives from the competent authorities, albeit together with the EBA Chair in the role of convenor and full voting member. ${ }^{126}$

The European Court of Auditors has reported unwillingness from competent authorities to escalate disputes to the EBA level. ${ }^{127}$ This finding makes it unsurprising that the Article 17 and Article 19 powers have had limited practical impact, not only in terms of the number of requests from competent authorities but also with respect to 'own initiative' use, since that use must necessarily reflect the views of those who make the decisions within the EBA. There is scope for empirical inquiry into the reasons for competent authorities' reticence with respect to these powers, but at an intuitive level it is understandable that the participants in a densely connected long-term network that relies for its efficient functioning on a high degree of trust and cooperation between the parties would shy away from more confrontational tools. Similar considerations may also inhibit EBA officers and staff from strongly promoting the use of the Article 17 and Article 19 powers.

Does it matter that the Article 17 and Article 19 powers may turn out to be of peripheral significance, with their impact confined mostly to a 'dissuasive effect' identified by the European Commission ${ }^{128}$ It could if the usage of these powers were to be deployed to measure the EBA's success or failure on the supervisory side, especially bearing in mind that formal EBA intervention seems even less likely in the post-SSM environment. However, to judge the EBA by those criteria would be misguided. Close examination of the intervention powers reveals that the EBA cannot plausibly be expected significantly to prove its value on the supervisory side through the use it makes of its intervention powers because those powers are an

\footnotetext{
123 EBA Rules of Procedure for investigation of breach of Union law (EBA/DC/2014/100, 14 July 2014).

124 EBA Rules of Procedure for the settlement of disagreements between competent authorities (EBA/ DC/2014/091, 20 February 2014).

125 EBA Regulation, Art. 44. Decisions are taken by simple majority but that majority must include a simple majority of votes from both SSM participating and non-participating Member States.

126 EBA Regulation, Art. 41 and the Rules of Procedure.

127 European Court of Auditors (2014), at p. 28.

128 European Commission (2014), at p. 7.
} 
uneasy fit with its hybrid structure and governance arrangements. The symbolic effect of these powers is important in its own right as was demonstrated, for example, in the immediate aftermath of the Greek bailout referendum when the EBA Chairman intervened in response to rumours of 'haircuts' to retail deposits to point out that such action would be against EU law and would lead 'immediately' to EBA intervention.

\subsection{Standardisation of Supervisory Processes}

Regulatory harmonisation facilitates supervisory harmonisation. An expanding rulebook can reduce the scope for supervisory discretion (for example, by eliminating discretions and options) and thus reduce the risk of inconsistencies where multiple supervisors are involved. However, there are also dangers of going too far in seeking to use regulation to eliminate entirely the need for supervisory judgment. A judgment-based approach to supervision avoids 'box ticking' by supervisors and allows for differentiated responses that are appropriately calibrated to the wide variety of supervised institutions. Judgment-based approaches have rapid-reaction advantages over regulation, which has a well-known tendency to lag behind market developments. Danièle Nouy, Chair of the Supervisory Board of the ECB, has spoken of the need to balance 'uniform supervisory anchor points with constrained supervisory judgment'. ${ }^{129}$ Nouy had in mind the needs of the SSM, where the ECB has now sought to regularise the exercise of judgment with respect to supervisory options and discretions in the EU legislative framework, ${ }^{130}$ but a balanced approached is also required at the EU level (subject to the important caveat that what works within the SSM may not necessarily be right for the EU as a whole).

What does the need for balance between uniformity and discretionary judgment in supervision mean for the EBA, bearing in mind the extra layer of complication that the establishment of the SSM adds to an already delicate exercise and the increasing demands it puts on the EBA with respect to maintaining the integrity of the Single Market? Matters of supervisory judgment are an extremely sensitive area for the EBA in its relations with the competent authorities. The EBA cannot simply dictate how supervisory judgment should be exercised, so it must find other ways to fulfil its mandate to play an active role in the development of a common supervisory culture $^{131}$ and to perform a coordination function. ${ }^{132}$

Given that the making of regulatory products is the EBA's 'comfort zone', it is not surprising that much of its effort in this regard has been concentrated on the production of technical standards and guidelines that seek to standardise supervisory

\footnotetext{
129 Nouy (2015).

130 The ECB has embarked upon an exercise to ensure consistency within the SSM with respect to the operation of options and discretions provided for in the legislative framework: Regulation (EU) 2016/445 of the European Central Bank of 14 March 2016 on the exercise of options and discretions available in Union law (ECB/2016/4) OJ 2016 L 78/60; ECB Guide on options and discretions available in Union law (March 2016), available at https://www.bankingsupervision.europa.eu/ecb/pub/pdf/ecb_guide_options_ discretions.en.pdf?62da619681f6f78cccd466076978160b. Accessed 13 June 2016.

131 EBA Regulation, Art. 29.

132 EBA Regulation, Art. 31.
} 
procedures and methodologies, and to establish uniform reporting requirements and formats. The SREP guidelines, discussed already, and the package of technical standards that specify in detail the framework for the annual supervisory benchmarking exercises foreseen by the CRDIV, Article 78, with respect to calculations for own-funds requirements, ${ }^{133}$ are standout examples, but there are also many others. ${ }^{134}$ The EBA commentary accompanying the SREP guidelines notes that the guidelines 'should be seen as guiding and not as restricting or limiting supervisory judgment ${ }^{135}$ but at the same time, competent authorities are enjoined to 'apply these guidelines in a way that will not compromise the intended harmonisation and convergence ${ }^{136}$; and the introduction of consistent methodologies is held out as an essential step for 'achieving more consistent prudential outcomes'. ${ }^{137}$ This rather coded language can be read as a subtle acknowledgement of the propensity of procedural standardisation to affect substantive behaviour and judgment. ${ }^{138}$ The drive towards convergence is further reinforced by obligations on competent authorities to inform the EBA on the operation of their SREP processes, and for the EBA in turn to report to the Parliament and Council. ${ }^{139}$ Peer review of SREP processes is also envisaged. ${ }^{140}$

The SSM-related conferral on the EBA of a specific mandate to develop a nonbinding handbook of 'supervisory best practices for methodologies and processes, ${ }^{141}$ also relies on the strategy of promoting consistency through processoriented guidance. Again the EBA treads warily, emphasising that the aim is to 'assist' supervisors and to 'support' the practical application of technical standards and guidelines and not to 'restrict judgment-led supervision'. ${ }^{142}$

The EBA can also point to other important strands of activity to demonstrate its growing contribution to improving the quality of pan-EU supervisory effectiveness. ${ }^{143}$ The evidence includes the significant capacity it has developed in the areas of data and information gathering, mapping and benchmarking of banks' and supervisory practices, analytical assessment, risk assessment reports and risk dashboards (of which work it has been said that although it is 'not equal in quality to the best-in-class produced at a Member State level, it is considered of sufficient

\footnotetext{
133 Detailed at https://www.eba.europa.eu/-/eba-delivers-benchmarking-package. Accessed 1 December 2015.

134 For an overview of some of this work: EBA (2014a), at pp. 40-41; EBA (2015b), at pp. 29-31 and 33.

135 EBA/GL/2014/13, supra n. 77, at p. 10.

136 Ibid.

137 Ibid, at p. 8. For the application of SREP methodology in the SSM context: ECB (2015), at pp. 51-57.

138 EBA (2015d), at p. 3.

139 CRDIV, Art. 107. The first report was delivered in April 2015: EBA (2015d).

140 CRDIV, Art. 107. See further: EBA (2015b), at p. 93.

141 EBA Regulation, Art. 29(2).

142 EBA (2015d), at p. 22.

143 For a general overview: EBA (2015b), at pp. 53-69.
} 
quality and frequency to add value to the risk assessment process within the ESFS $\left.{ }^{144}\right) .{ }^{145}$ The EBA has done particularly extensive work in the area of monitoring internal ratings-based approaches and the comparability of riskweighted assets. ${ }^{146}$ These analytical studies have brought greater transparency to bank practices that had provoked suspicion because of seemingly inexplicable variations in risk assessments, and have informed (or, less neutrally, provided ammunition for) the EBA's work on the technical standards for annual supervisory benchmarking exercises.

Highly technical, scientific and analytical work and other specialised EBA activity, such as the building of IT platforms and the coordination of supervisory training programmes (which is becoming an increasingly significant area of responsibility for the EBA), ${ }^{147}$ are not necessarily eye-catching but they are critical to the development of a common approach. Transparency-oriented obligations for competent authorities to inform the EBA of supervisory actions maintain the momentum. For example, a transparency obligation that goes to the core of prudential regulation is the obligation on competent authorities to inform the EBA of the capital instruments that they have classified as Common Equity Tier 1 capital instruments. ${ }^{148}$ The list, which is published, is monitored by the EBA and in a specific assertion of power to interpret the law and apply it correctly, it can remove from the list of instruments that do not meet the CRR criteria. ${ }^{149}$

The EBA's report on convergence of supervisory practices, published in April 2015 , provides a good illustration of the nature and significance of the technical side of its work. The report, based on information collected from NCAs and institutions, and from the EBA's own observations, including those drawn from the participation of EBA staff in colleges of supervisors, provides a very rich, broad and deep data source of 'on the ground' supervisory practices. ${ }^{150}$ The collection and analysis of so much detailed hard evidence gives authority and credibility to the EBA's evaluation of the progress made towards supervisory convergence, and also improves the evidence base for further steps. At a theoretical level, it can be commended for according well with experimentalist and other new governance approaches to regulation that emphasise the importance of 'learning by doing', structured learning processes, and reflexive responses.

It is evident from the supervisory convergence report that colleges of supervisors are a setting of particular importance for the EBA, ${ }^{151}$ and that they provide

\footnotetext{
144 Mazars (2013), at p. 69.

145 For overviews: EBA (2014a), at pp. 41-44; EBA (2015d), at pp. 22-24.

146 Detailed reports on the review on the consistency of risk-weighted assets are available at http://www. eba.europa.eu/risk-analysis-and-data/review-of-consistency-of-risk-weighted-assets. Accessed 1 December 2015. EBA (2015b), at pp. 24-27, provides an overview of the range of work in this area.

147 EBA (2015b), at pp. 57-59.

148 CRR, Art. 26.

149 CRR, Arts. 26 and 80. This power has been used on a number of occasions, most recently in October 2015: https://www.eba.europa.eu/-/eba-updates-list-of-common-equity-tier-1-cet1-capital-instrumen-1. Accessed 1 December 2015.

150 This report responds to the mandate in CRDIV, Art. 107.

151 EBA Regulation, Art. 21.
} 
opportunities both for mutual learning between all participants and for the EBA staff to experience and monitor the realities of cross-border supervisory practice. ${ }^{152}$ Colleges of supervisors are mandatory under the CRR/CRDIV framework ${ }^{153}$ to facilitate the coordination of supervisory activity and the making of joint decisions on institution-only prudential requirements. ${ }^{154}$ Colleges thus bring together the supervisors of cross-border banks and the EBA, and as the vehicle for supervisory coordination, they allow for the pooling of skills, knowledge and resources, and for collaborative working. Whilst it is the case that within the SSM colleges of supervisors have been replaced by joint supervisory teams, which are groups of supervisors coordinated by the ECB, and the ECB is itself intent on promoting supervisory consistency, ${ }^{155}$ nevertheless colleges remain important for cross-border groups with activities that extend beyond the SSM region. As elsewhere on the supervisory side, the EBA has played a facilitative role by standardising college working processes and procedures for joint decision-making, ${ }^{156}$ but the actual participation in colleges ${ }^{157}$ is a distinctive facet of the EBA's role that brings its staff into closer proximity with frontline supervision than other activities. This has included proximity to supervisory disagreements. ${ }^{158}$

In addition to its Article 19 intervention power discussed earlier, the EBA has a power as part of its coordination function (Article 31 of its founding instrument) to carry out non-binding mediation between competent authorities upon request or at its own initiative. ${ }^{159}$ This Article 31 power, which is not as restrictively drawn as the Article 19 power, has proved to be more palatable to competent authorities, and by the end of December 2015 there had been five non-binding mediation cases and one informal mediation case. The EBA, it has self-reported, has 'facilitated mutually agreeable solutions' ${ }^{160}$ This experience with Article 31 is consistent with the intuition that the EBA's route to success lies more in conciliation and subtle pressure than in direct confrontation. For reasons already discussed, a switch to a more aggressive stance would be unlikely to pay dividends in a post-SSM environment of potentially fewer colleges in which the ECB (taking the place of national authorities as the voting member) is likely to be a looming presence.

\footnotetext{
$\overline{152}$ EBA (2015d), at pp. 10 and 20-21. See also EBA (2015b), at pp. 53-55.

153 CRDIV, Art. 116. Resolution colleges are also required under BRRD, Art. 88.

154 CRDIV, Art. 113.

155 ECB (2015), at p. 8.

156 Relevant technical standards, guidelines and recommendations are accessible at http://www.eba. europa.eu/regulation-and-policy/colleges-of-supervisors. Accessed 1 December 2015.

157 CRDIV, Art. 116(1). EBA has a convening power: EBA Regulation, Art. 21(2). With respect to resolution colleges, EBA is a non-voting member: BRRD, Art. 88(4). EBA (2014a), at pp. 38-39, reports on supporting and monitoring college activities.

158 EBA (2015d), at p. 21.

159 EBA Regulation, Art. 31(c).

160 EBA (2015d), at p. 21. Also EBA (2015b), at p. 56.
} 


\subsection{Supervisory Activity and Internal Governance}

How does the EBA's governance model and organisational structure impinge on the activities discussed in this section? Non-binding mediation stands out as a context in which the officers and staff of the EBA have a particularly prominent role: under the relevant rules of procedure, the EBA Chair acts as the mediator to facilitate an agreement and it is only if a settlement cannot be reached that the panel becomes involved. ${ }^{161}$ More generally, the organisation and conduct of technical work is a context that lends itself to the assertion by the EBA of 'its own' authority within its hybrid structure: the EBA functions as a channel for the pooling of information, expertise, knowledge and experience drawn from national experience, but the EBA itself - that is, the EBA staff - can improve the quality and robustness of the work by bringing other qualities, such as systematic ordering and organisation, willingness (backed by legal power ${ }^{162}$ ) to scrutinise and challenge the collected information, detachment from national interests, expertise in making cross-border comparisons, and the maintenance of central databases. The EBA's panoptic gaze allows for multi-level, mutually reinforcing oversight, as exemplified by the CRDIV, Article 75 framework for remuneration policies where benchmarking by competent authorities is supplemented by EBA benchmarking of the data supplied to it by competent authorities from their local exercises. ${ }^{163}$

\subsection{The Danger of Responsibility Without Power: Stress Testing}

Stress testing of the resilience of banks to adverse economic developments is the market-facing supervisory activity for which the EBA has become most widely known. ${ }^{164}$ Yet the EBA's strong association with stress testing has not always played to its advantage. Difficult experiences with stress testing prompt questions less about the quantity of the EBA's contribution on the supervisory side than about its quality.

The EBA, in cooperation with the European Systemic Risk Board, has the power to initiate EU-wide stress tests ${ }^{165}$ but the actual conduct of EU-wide stress tests is a collaborative exercise involving, as well as the EBA, the European Commission, the European Systemic Risk Board, the ECB in its supervisory capacity and the national competent authorities. Stress testing is an activity in which the EBA has 'learnt by doing', not only with regard to the technicalities of stress testing but also as to the need to be robust and clear on exactly what the limits of its role are. The faulty 2011

\footnotetext{
161 EBA, Rules of Procedure for the non-binding mediation between competent authorities (EBA/DC/ 2014/093).

162 EBA Regulation, Art. 35.

163 E.g., EBA Benchmarking of approved higher ratios: 2014 data (November 2015). https://www.eba. europa.eu/documents/10180/950548/

Benchmarking+Report+on+Approved+Higher+Ratios+for+Remuneration.pdf. Accessed 13 June 2016.

164 EBA Regulation, Art. 32. EBA (2015b), at p. 9.

165 EBA Regulation, Art. 32(2). The EBA must consider at least annually whether it is appropriate to carry out testing: EBA Regulation, Art. 22(1a).
} 
stress test dealt a serious blow to the EBA's reputation, but unfairly so, because it was in effect saddled with a disproportionate share of the blame given the limitations of its mandate and powers.

The allocation of responsibilities was spelt out more clearly in the 2014 exercise where the EBA took the lead in setting the common methodology and a set of templates, hosted a central question-and-answer process to facilitate the calculation of stress results by banks, was responsible for ensuring coordination and cooperation between the competent authorities, and acted as a data hub for the dissemination of the results. ${ }^{166}$ Although the EBA's mandate and powers with respect to stress testing was strengthened in 2013 to reflect lessons learnt from previous exercises, in particular to equip the EBA to gather information directly from institutions and to request independent audits, ${ }^{167}$ in fact the competent authorities, including the ECB, remained responsible for the quality assurance of banks' results and for deciding on follow-up steps. ${ }^{168}$ The underlying adverse and baseline scenarios of the stress test were provided by the European Systemic Risk Board and the European Commission respectively. ${ }^{169}$ An innovation in 2014 was for the exercise to be linked to an asset quality review to ensure the validity and enhanced comparability of the starting point of the stress test. ${ }^{170}$ The EBA provided Article 16 recommendations for the organisation of that review. ${ }^{171}$

For the future, the presence of the SSM may help to put to bed any lingering confusion about the EBA's role in EU-wide stress tests because the more streamlined supervisory architecture should make it easier to see where responsibilities lie. A reasonably clear-cut allocation of responsibilities for the 2016 stress test exercise has been set out. ${ }^{172}$ This enhanced level of clarity should shield the EBA from one of the downsides of polycentric and interdependent systems of governance, namely lack of clarity on who is responsible for what.

\section{Conclusion}

The EBA is an independent EU agency of a hybrid nature. It was established in the period before deepening crisis made it politically palatable to give the ECB operational responsibility for banking supervision within EBU. The changed circumstances have put the EBA's future relevance in doubt. This article has taken the view that there is still a role for the EBA to play as the 'glue' between EBU and the Single Market. The article does not rule out the possibility of reforms to improve the EBA's ability to discharge this responsibility, but its distinctive claim lies in its

\footnotetext{
166 EBA (2014d), para. 2.3; EBA (2015b), at pp. 65-68; ECB (2015), at pp. 43-47.

167 EBA Regulation, Art. 32(3a).

168 EBA (2014d), para. 2.3.

169 Ibid.

170 Ibid.

171 EBA Recommendation on asset quality reviews (EBA/REC/2013/04).

172 EBA (2015e).
} 
relatively optimistic assessment of what the EBA can already do within the limitations of its existing set-up or with only modest changes.

The analysis has proceeded from the view that, broadly speaking, it is a welcome feature of an institutional architecture for frontline supervisors to play a central role in the development of regulation and supervision. Therefore, the EBA's current governance model should not be condemned simply because its principal decisionmaking organ is a Board of Supervisors, comprised of representatives from the national supervisors. The article has demonstrated that the intergovernmental 'club'-like aspects of the EBA's governance and organisational structure have not prevented it from making a significant contribution to regulatory harmonisation. The expertise it has amassed in regulatory product development has also benefitted the supervisory side of its mandate, where the EBA has facilitated progress in smoothing out supervisory inconsistencies through rules and guidance that standardise procedures and processes. In addition, the article has pointed to a range of ways, not all process-oriented, in which the EBA, itself not a frontline supervisor, can claim to be making a substantive difference to the way that supervision is conducted in the EU.

The article has accepted that the EBA's governance model does much to explain the EBA's reticence to deploy more confrontational powers and why it functions more as a manager and coordinator of supervisors than as a director. It has become clear that the originally much-vaunted intervention powers are actually likely to be rather peripheral to the EBA's capacity to play a valuable role in supervision. The governance model has also been cited as a possible reason why there has been relatively little enthusiasm for the peer review tool, ${ }^{173}$ although there are other possible explanations for its under-utilisation thus far. ${ }^{174}$

Yet, that its effectiveness relies more on facilitation than on threats suggests that the EBA is well equipped to make progress in its role as the unifying agent between the SSM and the Single Market; confrontation seems unlikely to be the route to productive relations with the ECB and the competent authorities of the nonparticipating Member States. The styles that have come to characterise the EBA's working methods thus far should also be conducive to good outcomes in the resolution context.

The inquiry conducted in this article has been placed within lines of governance scholarship that have moved away from simple 'command and control' models to more complex frameworks that seek to provide a more nuanced understanding of the diverse institutions and structures that have evolved to address the multifaceted character of problems faced by contemporary society. Since study of the EBA requires engagement within multiple layers of institutional complexity - within the EBA, between the EBA and SSM/EBU, and between the EBA and the rest of the ESFS (the dizzying array of acronyms alone effectively conveys a sense of the

\footnotetext{
173 Mazars (2013), at pp. 15 and 67 (referring to lack of independence in the peer review methodology); IMF (2013b), at p. 14.

174 There are sequencing issues: a regulatory framework needs to be in place before formal reviews of implementation practices can occur: European Commission (2014), at p. 6. Also relevant, of course, is that work programmes have been overwhelmed by the pressure to produce regulatory products. Peer review activity is starting to build: EBA (2015b), at p. 57.
} 
intricacies) - this branch of scholarly inquiry provides appropriate and fruitful sources to draw upon.

The understanding of the EBA that emerges from this inquiry also has promise as a different perspective on practical concerns. The view that the EBA's resource constraints are a temporary problem that will fade as the pressure to function as a rules factory recedes is challenged by the clearer picture of where the EBA can add value on the supervisory side that is starting to emerge. Whilst the shift from the rule-making to the implementation phase should allow for some re-allocation of existing resources, additional investment targeted towards the areas where the EBA can do most to improve the quality and consistency of supervision may be needed for the EBA fully to realise its potential.

Open Access This article is distributed under the terms of the Creative Commons Attribution 4.0 International License (http://creativecommons.org/licenses/by/4.0/), which permits unrestricted use, distribution, and reproduction in any medium, provided you give appropriate credit to the original author(s) and the source, provide a link to the Creative Commons license, and indicate if changes were made.

\section{References}

Armstrong K (2011) The character of EU law and governance: from 'community method' to new modes of governance. Curr Legal Probl 64:179-214

Armstrong K, Kilpatrick C (2007) Law, governance, or new governance-the changing open method of coordination. Columbia J Eur Law 13:649-677

Banking Stakeholder Group (2015) Response to consultation EBA/CP/2014/41. https://www.eba.europa. eu/documents/10180/911034/BSG+response+to+Consultation+Paper+\%28EBA-CP-2014-41\% 29\%20-+26+February+2015.pdf. Accessed 1 Dec 2015

Binham C (2015) Three lenders face probe by ECB banking watchdog. ft.com, 31 March 2015

Brown EF (2015) Consolidated financial regulation: six national case studies and the experience of the European Union. https://volckeralliance.org/sites/default/files/attachments/Background\%20Paper\% 202_Consolidated\%20Financial\%20Regulation \%20-\%20Six \%20National $\% 20$ Case $\% 20$ Studies $\%$ 20and $\% 20$ the $\% 20$ Experience $\% 20$ of $\% 20$ the\%20European\%20Union.pdf. Accessed 1 Dec 2015

Campbell-Verduyn M, Porter T (2014) Experimentalism in European Union and global financial governance: interactions, contrasts, and implications. J Eur Public Policy 21:408-429

Cappiello S (2015) The EBA and the Banking Union. Eur Bus Org Law Rev 16:421-437

Craig PP (2015) Comitology, rulemaking and the Lisbon settlement: tensions and strains. In: Bergstrom CF, Ritleng D (eds) Rulemaking by the Commission: the new system. Oxford University Press, Oxford

de Búrca G (2010) New governance and experimentalism: an introduction. Wisconsin Law Rev 101-112

de Búrca G, Keohane RO, Sabel CF (2013) New modes of pluralist global governance. NY Univ J Int Law Polit 45:723-786

de Búrca G, Keohane RO, Sabel CF (2014) Global experimentalist governance. Br J Polit Sci 44:477-486 de Larosière J et al (2009) High Level Group on Financial Supervision in the EU, chaired by Jacques de Larosière. Brussels, European Commission, 25 February 2009

ECOFIN (2014) Council conclusions on the ESFS review, 7 November 2014. http://www.consilium. europa.eu/uedocs/cms_data/docs/pressdata/en/ecofin/145696.pdf. Accessed 13 June 2016

European Banking Authority (EBA) (2014a) Annual report 2013. https://www.eba.europa.eu/documents/ 10180/699921/EBA+2013+Annual+Report.pdf/202f6619-7888-4345-8fa1-fb4aae03ae23. Accessed 1 Dec 2015

European Banking Authority (EBA) (2014b) Annual work programme 2015. https://www.eba.europa. eu/-/eba-releases-work-plans-for-2015. Accessed 13 June 2016 
European Banking Authority (EBA) (2014c) Second report on impact assessment for liquidity measures under Article 509(1) of the CRR. https://www.eba.europa.eu/documents/10180/950548/ 2014+LCR+IA+report.pdf. Accessed 1 Dec 2015

European Banking Authority (EBA) (2014d) Results of 2014 EU-wide stress test. https://www.eba. europa.eu/documents/10180/669262/2014+EU-wide+ST-aggregate+results.pdf. Accessed 1 Dec 2015

European Banking Authority (EBA) (2015a) Addendum to 2015 work programme. https://www.eba. europa.eu/documents/10180/842038/Addendum+to+EBA+2015+Work+Programme_ March+2015.pdf. Accessed 13 June 2016

European Banking Authority (EBA) (2015b) Annual report 2014. http://www.eba.europa.eu/documents/ 10180/1112872/EBA+2014+Annual+Report.pdf/6d0a5f50-4d01-4867-bcf3-4fa8091719a4.

Accessed 1 Dec 2015

European Banking Authority (EBA) (2015c) EBA report on the publication of administrative penalties on an anonymous basis (EBA/Op/2015/18). https://www.eba.europa.eu/documents/10180/983359/ EBA-Op-2015-

18+Report+on+publication+of+administrative+penalties + on + anonymous + basis.pdf. Accessed 1 Dec 2015

European Banking Authority (EBA) (2015d) EBA report on convergence of supervisory practices. https:// www.eba.europa.eu/documents/10180/950548/Supervisory+convergence+report.pdf/9f49ddf9232f-4062-b34e-ff671d440081. Accessed 1 Dec 2015

European Banking Authority (EBA) (2015e) EBA announces details of 2016 EU-wide stress test. 5 November 2015. https://www.eba.europa.eu/-/eba-announces-details-of-2016-eu-wide-stress-test. Accessed 1 Dec 2015

European Banking Federation (2015) Response to consultation on draft regulatory technical standards on contractual recognition of bail-in. http://www.ebf-fbe.eu/wp-content/uploads/2015/02/EBF_012539EBF-Response-EBA-CP-2014-33-on-contractual-bail-in-v3-clean-2.pdf. Accessed 1 Dec 2015

European Central Bank (ECB) (2014) Guide to banking supervision. https://www.bankingsupervision. europa.eu/ecb/pub/pdf/ssmguidebankingsupervision201411.en.pdf. Accessed 1 Dec 2015

European Central Bank (ECB) (2015) Annual report on supervisory activities 2014. https://www. bankingsupervision.europa.eu/press/publications/annual-report/html/index.en.html. Accessed $1 \mathrm{Dec}$ 2015

European Commission (2014) The operation of the European Supervisory Authorities (ESAs) and the European System of Financial Supervision (ESFS) COM(2014) 509 final

European Commission (2015a) Green paper: building a Capital Markets Union (COM)2015 63 final

European Commission (2015b) Financial benchmarks: Commission welcomes agreement on new rules to prevent manipulation, 25 November 2015. http://europa.eu/rapid/press-release_STATEMENT-156169_en.htm. Accessed 1 Dec 2015

European Court of Auditors (2014) European banking supervision taking shape-EBA and its changing context. Special Report No 5. http://www.eca.europa.eu/Lists/ECADocuments/SR14_05/SR14_05_ EN.pdf. Accessed 1 Dec 2015

Everson M, Vos E (2014) European agencies: what about institutional balance? In: Blockmans S, Lazowski A (eds) Research handbook on EI institutional law. Edward Elgar Publishing, Cheltenham

Everson M, Monda C, Vos E (eds) (2014) EU Agencies in between institutions and Member States. Kluwer Law International, Alphen aan den Rijn

Héritier A, Lehmkuhl D (2008) The shadow of hierarchy and new modes of governance. J Public Policy 28:1-17

House of Lords European Union Committee (2015) The post-crisis EU financial regulatory framework: do the pieces fit? HL Paper 103. http://www.publications.parliament.uk/pa/ld201415/ldselect/ 1deucom/103/103.pdf. Accessed 1 Dec 2015

International Monetary Fund (IMF) (2013a) European Union: publication of financial sector assessment program documentation - technical note on issues in transparency and accountability. IMF Country Report No 13/65

International Monetary Fund (IMF) (2013b) European Union: publication of financial sector assessment program documentation - technical note on European Banking Authority. IMF Country Report N0 $13 / 74$

Masters B (2013) How will the tide of regulatory change affect the City? ft.com, 11 June 2013 
Mathieu E (2014) Networks, committees or agencies? The many faces of the EU regulatory space. ECPR Regulatory and Governance Standing Group IBEI. http://reggov2014.ibei.org/bcn-14-papers/54179.pdf. Accessed 1 Dec 2015

Mazars (2013) Review of the new European System of Financial Supervision. http://www.europarl. europa.eu/RegData/etudes/etudes/join/2013/507446/IPOL-ECON_ET\%282013\%29507446_EN. pdf. Accessed 1 Dec 2015

Moloney N (2013) Resetting the location of regulatory and supervisory control over EU financial markets: lessons from five years on. Int Comp Legal Quart 62:955-965

Moloney N (2014a) EU securities and financial markets regulation, 3rd edn. Oxford University Press, Oxford

Moloney N (2014b) European Banking Union: assessing its risks and resilience. Common Market Law Rev 51:1609-1670

Nouy D (2015) Presentation of the first ECB annual report on supervisory activities by the Chair of the ECB's Supervisory Board at the European Parliament's Economic and Monetary Affairs Committee, 31 March 2015. https://www.bankingsupervision.europa.eu/press/speeches/date/2015/ html/se150331.en.html. Accessed 1 Dec 2015

Posner E (2010) The Lamfalussy Process: polyarchic origins of networked financial rule-making in the EU. In: Sabel CF, Zeitlin J (eds) Experimentalist governance in the European Union. Oxford University Press, Oxford

Ritleng D (2015) The dividing line between delegated and implementing acts: the Court of Justice sidesteps the difficulty. Common Market Law Rev 52:243-257

Sabel CF, Zeitlin J (2010) Experimentalist governance in the European Union. Oxford University Press, Oxford

Thaler RH, Sunstein CR (2008) Nudge: improving decisions about health, wealth and happiness. Yale University Press, New Haven

Tröger TH (2014) The Single Supervisory Mechanism. Panacea or quack banking regulation? Preliminary assessment of the new regime for the prudential supervision of banks with ECB involvement. Eur Bus Org Law Rev 15:449-497

Wolfers B, Voland T (2014) Level the playing field: the new supervision of credit institutions by the European Central Bank. Common Market Law Rev 51:1463-1495

Zeitlin J (2015) Extending experimentalist governance: the European Union and transnational regulation. Oxford University Press, Oxford

Zeitlin J (2016) EU experimentalist governance in times of crisis. West Eur Polit. doi:10.1080/01402382. 2016.1181873 